\title{
Peran Pemoderasi Kepemilikan Institusional pada Pengaruh Beban Pajak Tangguhan, Perencanaan Pajak dan Kepemilikan Manajerial terhadap Manajemen Laba Akrual
}

\author{
Khuwailid ${ }^{1}$, Nur Hidayat ${ }^{2}$ \\ ${ }^{1}$ Universitas Pancasila, Jl. Srengseng Sawah, Jagakarsa, Jakarta Selatan, 12640 \\ ${ }^{2}$ Universitas Jenderal Achmad Yani, Jl. Terusan Jenderal Gatot Subroto, Bandung, Jawa Barat 40285
}

INFO ARTIKEL

JEL Classsification:

G32

H25

M41

Keywords:

deferred tax expense, tax planning,

managerial ownership, institutional ownership

and earnings

management accrual.

\section{ABSTRACT}

The purpose of this research is to identify, analyze, observe and test the deferred tax expense, tax planning, managerial ownership and institutional ownership as a moderating towards accrual earnings managementcompanies of oil and gas sector listed at the Indonesia Stock Exchange within 2011-2015 period. In this study, the total populations used are 45 financial reports of oil and gas companies listed in Indonesia Stock Exchange (BEI). The tests method is using Moderated Regression Analysis (MRA). Two groups of variables are used the accrual earnings management (as the dependent variable), and three independent variables (the deferred tax expense, tax planning and managerial ownership), and institutional ownership (as a variable moderation). The research data were tested by moderated regression analysis and residual test is used as an analytical technique. These results indicate that institutional ownership is able to moderate the relationship between deferred tax expense and managerial ownership on accrual earnings management while institutional ownership was not able to moderate the tax planning to the management of accrual earnings.

\begin{abstract}
A B S T RA K
Penelitian ini bertujuan untuk mengetahui, menganalisis, membuktikan dan menguji beban pajak tangguhan, perencanaan pajak kepemilikan manajerial dan kepemilikan institusional sebagai pemoderasi terhadap manajemen laba akrualpada perusahaan pertambangan sektor minyak dan gas bumi yang terdaftar di Bursa Efek Indonesia periode 2011-2015. Dalam penelitian ini yang menjadi populasi adalah sebanyak 45 laporan keuangan perusahaan pertambangan sektor minyak dan gas bumi yang terdaftar di Bursa Efek Indonesia (BEI). Pengujian menggunakan moderated regression analysis (MRA). Untuk variable yang di gunakan adalah manajemen laba akrual (variabel dependen) dengan tiga variabel independen (beban pajak tangguhan, perencanaan pajak dan kepemilikan manajerial) dan kepemilikan institusional (variabel moderasi). Data penelitian diuji dengan cara analisis regresi moderasi (moderated regression analysis) serta uji residual digunakan sebagai teknik analisis. Hasil penelitian ini menunjukan bahwa kepemilikan institusional mampu memoderasi hubungan antara beban pajak tangguhan dan kepemilikan manajerial terhadap manajemen laba akrual sedangkan kepemilikan institusional tidak mampu memoderasi perencanaan pajak terhadap manajemen laba akrual.
\end{abstract}

*Email Korespondensi: '1wailid28@yahoo.co.id, 2jnur_hidayat@yahoo.co.id 


\section{Pendahuluan}

Manajemen selaku pihak internal perusahaan memiliki kepentingan dalam melakukan upaya peningkatan kualitas laba. Wiryandari dan Yulianti (2009) menyatakan bahwa laba yang berkualitas adalah laba yang dapat mencerminkan kelanjutan laba (sustainable earnings) di masa depan, yang ditentukan oleh komponen akrual dan kas, dapat mencerminkan kinerja keuangan perusahaan yang sesungguhnya. Semakin berkualitas laba perusahaan, maka investor semakin tertarik untuk menjadi salah satu pemilik saham perusahaan tersebut. Namun demikian, di sisi lain manajemen perusahaan juga menginginkan untuk meminimalkan laba kena pajak yang dilaporkan untuk keperluan pajak (Ettredge et al., 2008). Langkah yang kemudian diambil agar keduanya dapat dicapai adalah dengan memanipulasi laba menjadi lebih tinggi untuk pelaporan keuangan tapi tidak untuk pelaporan pajaknya.

Adapun kondisi yang terjadi di lapangan seperti PT. Kimia Farma Tbk. Pada tahun 2002 mengindikasikan adanya praktik manajemen akrual dengan menaikan laba hingga Rp 32,7 milyar, sama dengan PT. Indofarma pada tahun 2004 dengan menaikan laba bersih senilai Rp 28,870 milyar, sebagai dampak dari penilaian persediaan barang dalam proses yang lebih tinggi dari yang seharusnya, sehingga harga pokok penjualan tahun tersebut understated. Praktik manajemen laba sudah lumrah dilakukan oleh para manajer untuk menghindari pelaporan kerugian dengan berbagai motivasi manajemen laba, karena perusahaan tersebut tidak menerapkan prinsip GCG (Good Corporate Governance) dan fenomena yang terjadi adalah timbulnya masalah keagenan.

Manajemen laba akrual murni (pure accrual) yaitu dengan discretionary accrual yang tidak memiliki pengaruh terhadap arus kas secara langsung yang disebut dengan manajemen laba akrual. Manajemen laba akrual dilakukan pada akhir periode ketika manajer mengetahui laba sebelum direkayasa sehingga dapat mengetahui berapa besar manipulasi yang diperlukan agar target laba tercapai. Sistem akuntansi akrual sebagaimana yang ada pada prinsip akuntansi yang diterima umum memberikan kesempatan kepada manajer untuk rnembuat pertimbangan akuntansi yang akan memberi pengaruh kepada pendapatan yang dilaporkan. Dalam hal ini pendapatan dapat dimanipulasi melalui discretionary accruals (Gumanti, 2000).

Waluyo (2014) menyatakan bahwa Beban pajak tangguhan adalah jumlah beban (penghasilan) pajak tangguhan yang muncul akibat adanya pengakuan atas liabilitas atau aset pajak tangguhan. Beban pajak tangguhan akan menimbulkan liabilitas pajak tangguhan. Sedangkan menurut Phillips et.al (2003) menemukan bahwa beban pajak tangguhan dapat digunakan untuk memprediksi praktik manajemen laba oleh manajemen dengan dua tujuan yaitu untuk menghindari penurunan laba dan menghindari kerugian. Oleh karena itu peran manajer sangat penting dalam mengelola perusahaan.

Yin dan Cheng (2004) berpendapat bahwa upaya meminimalkan pembayaran pajak perusahaan dibatasi oleh perencanaan pajaknya. Pada umumnya, perencanaan pajak (tax planning) merujuk kepada proses merekayasa usaha dan transaksi Wajib Pajak agar utang pajak berada dalam jumlah yang minimal, tetapi masih dalam bingkai peraturan perpajakan. Namun demikian, perencanaan pajak juga dapat diartikan sebagai perencanaan pemenuhan kewajiban perpajakan secara lengkap, benar, dan tepat waktu sehingga dapat secara optimal menghindari pemborosan sumber daya. Tindakan manajemen laba ditentukan pula oleh motivasi manajer perusahaan, dalam hal ini terkait dengan kepemilikan manajerial. kepemilikan manajerial merupakan kepemilikan saham yang dimiliki oleh manajemen secara aktif ikut mengambil keputusan menurut Catherine (2013).

Peningkatan kepemilikan manajerial dari pemberian kompensasi untuk manajer akan 
mengakibatkan seorang manajer ikut dalam menentukan kebijakan dan pengambilan keputusan terhadap metode akuntansi yang diterapkan pada perusahaan yang mereka kelola. Hal itu berarti besarnya saham yang dimiliki mempunyai pengaruh terhadap kebijakan perusahaan. Struktur kepemilikan lain yaitu kepemilikan institusional, dimana umumnya dapat bertindak sebagai pihak yang memonitor perusahaan. Menurut Faizal (2004), perusahaan dengan kepemilikan institusional yang besar mengindikasikan kemampuannya untuk memonitor manajemen. Semakin besar kepemilikan institusional maka semakin efisien pemanfaatan aktiva perusahaan dan diharapkan juga dapat bertindak sebagai pencegahan terhadap pemborosan yang dilakukan oleh manajemen.

Beberapa penelitian sebelumnya telah melakukan studi manajemen laba di kisaran perpajakan dan kepemilikan manajerial. Adapun penelitian mengenai beban pajak tangguhan di Indonesia dilakukan oleh beberapa peneliti antara lain penelitian yang dilakukan oleh Peneliti fitriany (2016) menunjukkan bahwa beban pajak tangguhan tidak berpengaruh signifikan terhadap manajemen laba dan menurut Aziz (2015) bahwa beban pajak tangguhan secara parsial berpengaruh negatif terhadap praktik manajemen laba. Sedangkan penelitian yang dilakukan oleh Ulfa (2013) menunjukkan bahwa beban pajak tanggungan berpengaruh positif terhadap manajemen laba dan perencanaan pajak berpengaruh positif terhadap manajemen laba.

Penelitian yang dilakukan oleh Aditama dan Purwaningsih (2016) menyatakan bahwa perencanaan pajak tidak berpengaruh positif terhadap earnings management. Sedangkan penelitian Santana dan Wirakusuma (2016) menyatakan bahwa perencanaan pajak memiliki pengaruh positif, semakin tinggi perencanaan pajak maka semakin besar peluang perusahaan melakukan praktek manajemen laba. Sedangkan kepemilikan menajerial tidak berpengaruh terhadap praktek manajemen laba, artinya saham yang dimiliki oleh pihak manajer tidak sebanding dengan saham yang dimiliki perusahaan ataupun pihak luar. Saham yang dimiliki oleh pihak manajer tidak akan mampu memberikan dampak dalam pengambilan keputusan.

Penelitian Sukartha (2008), mengungkapkan bahwa kepemilikan manajerial terhadap saham perusahaan target akuisisi berpengaruh positif dan signifikan secara statistics pada kesejahteraan pemegang saham perusahaan target saat publikasi terakhir sebelum akuisisi.

\section{Telaah Teori dan Pengembangan Hipotesis}

\section{Teori Keagenan (Agency Theory)}

Konsep manajemen laba dapat dimulai dari pendekatan teori agensi (agency theory). Jensen dan Meckling (1976) menyatakan bahwa hubungan keagenan merupakan sebuah kontrak antara manajemen (agent) dengan investor (principal). Pandangan agency theory yakni adanya pemisahan antara pihak principal dan agent yang menyebabkan munculnya potensi konflik yang dapat mempengaruhi kualitas laba yang dilaporkan. Maksud dengan principal dalam teori keagenan ini yakni pemegang saham atau pemilik yang menyediakan fasilitas dan dana untuk kebutuhan operasi perusahaan sedangkan agent adalah manajemen yang memiliki kewajiban mengelola perusahaan sebagaimana yang telah diamanahkan principal kepadanya menurut Sanjaya dan Sulistyanto (2004).

Teori agensi mengasumsikan bahwa masingmasing individu semata-mata termotivasi oleh kesejahteraan dan kepentingan dirinya sendiri. Pihak principal termotivasi mengadakan kontrak untuk menyejahterakan dirinya melalui pembagian dividen atau kenaikan harga saham perusahaan. Sedangkan pihak agent termotivasi untuk meningkatkan kesejahteraannya melalui peningkatan kompensasi. Konflik kepentingan semakin meningkat ketika principal tidak memiliki informasi yang cukup tentang kinerja 
agent karena ketidak mampuan principal memonitor aktivitas agent dalam perusahaan. Ditambah lagi agent mempunyai lebih banyak informasi mengenai kapasitas diri, lingkungan kerja, dan perusahaan secara keseluruhan. Hal inilah yang mengakibatkan adanya ketidakseimbangan informasi yang dimiliki oleh principal dan agent dan dikenal dengan istilah asimetri informasi. Asimetri informasi dan konflik kepentingan yang terjadi antara principal dan agent mendorong pihak agent untuk menyembunyikan beberapa informasi yang tidak diketahui oleh principal dan menyajikan informasi yang tidak sebenarnya kepada principal, terutama informasi tersebut berkaitan dengan pengukuran kinerja agent.

Konflik kepentingan yang terjadi antara manajer dengan pemegang saham akan mengakibatkan biaya keagenan (agency cost). Biaya keagenan dapat diminimalkan dengan suatu mekanisme pengawasan yang dapat mensejajarkan kepentingan yang terkait tersebut. Pemegang saham akan berusaha menjaga agar pihak manajemen tidak terlalu banyak memegang kas karena kas yang banyak akan merangsang pihak manajemen untuk menikmati kas tersebut bagi kepentingan dirinya sendiri.

\section{Teori Akuntansi Positif (Positive Accounting Theory)}

Teori akuntansi positif merupakan teori yang mencoba untuk membuat prediksi yang bagus dari kejadian dunia nyata. Teori akuntansi positif berkaitan dengan memprediksi tindakan seperti pilihan kebijakan akuntansi oleh manajer perusahaan dan bagaimana respon manajer tersebut terhadap standar akuntansi baru yang diusulkan Scott (2003). Menurut Watts dan Zimmerman (1990) Teori akuntansi positif yaitu berusaha untuk menjelaskan fenomena akuntansi yang diamati berdasarkan pada alasan-alasan yang menyebabkan terjadinya suatu peristiwa. Maksudnya, teori akuntansi positif dimaksudkan untukmenjelaskan dan memprediksi konsekuensi yang terjadi jika manajer menentukan pilihan tertentu. Penjelasan dan prediksi dalam teori akuntansi positif didasarkan pada proses kontrak atau hubungan keagenan antara manajer dengan kelompok lain seperti investor, kreditor, auditor, pihak pengelola pasar modal dan institusi pemerintah. Sealin itu, Watt dan Zimmerman (1986) juga mengaitkan Positive accounting theory dengan fenomena perilaku oportunistik manajer dengan membentuk tiga hipotesis yang melatar belakangi perilaku oportunistik manajer tersebut, yaitu:

1) Bonus Plan Hypothesis, yakni manajemen akan memilih metode akuntansi yang memaksimalkan utilitasnya yaitu bonus yang tinggi. Manajer perusahaan yang memberikan bonus besar berdasarkan earnings lebih banyak menggunakan metode akuntansi yang meningkatkan laba yang dilaporkan.

2) Debt Covenant Hypothesis, yakini manajer perusahaan yang melakukan pelanggaran perjanjian kredit cen-derung memilih metode akuntansi yang memiliki dampak meningkatkan laba menurut Sweeney (1994). Hal ini untuk menjaga reputasi mereka dalam pandangan pihak eksternal.

3) The Political Cost Hypothesis, yakni bahwa perusahaan yang berhadapan dengan biaya politik, cenderung melakukan rekayasa penurunan laba dengan tujuan untuk meminimalkan biaya politik yang harus mereka tanggung. Biaya politik mencakup semua biaya yang harus ditanggung oleh perusahaan terkait dengan regu-lasi pemerintah, subsidi pemerintah, tarif pajak, tuntutan buruh dan lain sebagainya menurut Scott (2000).

\section{Manajemen Laba Akrual}

Manajemen laba dapat terjadi karena penyusunan laporan keuangan menggunakan dasar akrual. Sistem akuntansi akrual sebagaimana yang ada pada prinsip akuntansi yang diterima umum memberikan kesempatan kepada manajer untuk rnem-buat pertimbangan 
akuntansi yang akan memberi pengaruh kepada pendapatan yang dilaporkan. Dalam hal ini pendapatan dapat dimanipulasi melalui discretionary accruals (Gumanti, 2000).

Discretionary accruals merupakan model yang digunakan manajemen untuk mela-kukan praktik meratakan laba, sedangkan menurut Syahril (2016) manajemen akrual muncul dari laba akuntansi (akrual) sebagai tesa dengan manajemen laba sebagai antitesa melahirkan manajemen akrual.

Akrual merupakan selisih antara kas masuk bersih dari hasil operasi perusahaan dengan laba yang dilaporkan dalam laporan laba-rugi, yang bisa bersifat discretionary accruals dan non-discretionary accruals menurut Sulistyanto (2008). Gumanti (2000) menjelaskan transaksi akrual bisa berwujud antara lain:

1. Transaksi yang bersifat non-discretionary accruals, yaitu apabila transaksi telah dicatat dengan metode tertentu maka manajemen diharapkan konsisten dengan metode tersebut.

2. Transaksi yang bersifat discretionary accruals, yaitu metode yang mem-berikan kebebasan kepada manajemen untuk menentukan jumlah transaksi akrual secara fleksibel.

\section{Beban Pajak Tangguhan}

Menurut Phillips, et al. (2003), beban pajak tangguhan adalah beban yang timbul akibat perbedaan temporer antara laba akuntansi (yaitu laba dalam laporan keuangan untuk kepentingan pihak eksternal) dengan laba fiskal (laba yang digunakan sebagai dasar perhitungan pajak). Perbedaan antara laporan keuangan akuntansi dan fiskal disebabkan dalam penyusunan laporan keuangan, standar akuntansi lebih memberikan keleluasaan bagi manajemen dalam menentukan prinsip dan asumsi akuntansi dibandingkan dengan yang diperbolehkan menurut peraturan perpajakan.

Beban pajak tangguhan merupakan akun yang muncul pada laporan laba rugi sebagai akibat dari adanya perbedaan temporer yang memiliki koreksi negatif lebih besar dari koreksi positif. Beban pajak tangguhan juga merupakan nilai dari perubahan yang terjadi atas aktiva pajak tangguhan (deferred tax assets) dan kewajiban pajak tangguhan (deferred tax liabilities) yang dilaporkan perusahaan dalam laporan keuangan tahun berjalan. Beban pajak tangguhan akan naik seiring dengan meningkatnya kewajiban pajak tangguhan bersih. Kewajiban tang-guhan bersih tersebut diperoleh dari selisih antara kewajiban pajak tangguhan dengan aktiva pajak tangguhan menurut Djamaluddin, dkk (2008).

\section{Perencanaan Pajak}

Perencanaan pajak merupakan salah satu bentuk dari fungsi manajemen pajak dalam upaya melakukan penghematan pajak secara legal. DR.Arles.P. Ompusunggu (2011), dalam bukunya yang berjudul Cara Legal Siasati Pajak menyatakan bahwa Tax Planning adalah suatu kapasitas wajib pajak untuk mengatur aktivitas keuangan yang dapat meminimalkan pembayaran pajak. Adapun pengertian perencanaan pajak (Tax Planning) menurut Erly Suandy (2011), adalah sebagai berikut Perencanaan Pajak adalah analisis sistematis dari berbagai pemilihan pajak yang berbeda, yang bertujuan meminimalkan kewajiban dalam tahun berjalan untuk periode yang akan datang.

Perencanaan pajak (Tax Planning) merupakan langkah awal dalam melakukan manajemen pajak. Pada tahap ini dilakukan pengumpulan dan penelitian terhadap peraturan perpajakan agar dapat diseleksi jenis tindakan penghematan yang akan dilakukan. Pada umumnya penekanan perencanaan pajak adalah untuk meminimumkan kewajiban pajak. Lumbantoruan (1996) mendefinisikan manajemen pajak sebagai sarana untuk memenuhi kewajiban perpajakan dengan benar, akan tetapi jumlah pajak dapat ditekan serendah mungkin untuk memperoleh laba dan likuiditas yang akan diharapkan oleh pihak manajemen. 


\section{Kepemilikan Manajerial}

Kepemilikan manajemen adalah proporsi pemegang saham dari pihak manajemen yang secara aktif ikut dalam pengambilan keputusan perusahaan (direktur dan komisaris) menurut Diyah dan Erman (2009). Dengan adanya kepemilikan mana-jemen dalam sebuah perusahaan akan menimbulkan dugaan yang menarik bahwa nilai perusahaan meningkat sebagai akibat kepemilikan manajemen yang meningkat. Kepemilikan oleh manajemen yang besar akan efektif memonitoring aktivitas perusahaan.

Shliefer dan Vishny (2006) menyatakan bahwa kepemilikan saham yang besar dari segi nilai ekonomisnya memiliki insentif untuk memonitor. Menurut Jensen dan Meckling (1976), ketika kepemilikan saham oleh manajemen rendah maka ada kecenderungan akan terjadinya perilaku opportunistic manajer yang meningkat akan juga. Dengan adanya kepemilikan manajemen terhadap saham perusahaan maka dipandang dapat menyelaraskan potensi perbedaan kepentingan antara manajemen dan pemegang saham lainnya sehingga permasalahan antara agen dan prinsipal diasumsikan akan hilang apabila seorang manajer juga sekaligus sebagai pemegang saham.

\section{Beban Pajak Tangguhan Terhadap Mana- jemen Laba Akrual}

Perusahaan dalam memilih kebijakan akuntansi, dapat dengan bebas memilih kebijakan akuntansinya, akan tetapi peraturan perpajakan sudah menetapkan kebijakan akuntansi yang harus digunakan, sehingga dalam pelaporan pajak perusahaan tidak dapat bebas menggunakan metode akuntansi. Menurut Yulianti (2005).

Menurut Yulianti (2005), Abdul Rafay and Mobeen Ajmal (2014), Hakim dan praptoyo (2015) juga menemukan bukti empiris bahwa beban pajak tangguhan memiliki hubungan positif signifikan dengan proba-bilitas perusahaan untuk melakukan manajemen laba guna menghindari kerugian perusahaan. Oleh karena itu perbedaan antara laba akuntansi dan penghasilan kena pajak akan merefleksikan tingkat kebijakan manajer dalam memanipulasi laba menjadi lebih tinggi.

Berdasarkan dari teori akuntansi positif dan beberapa hasil penelitian diatas maka dapat diasumsikan bahwa dengan adanya beban pajak tangguhan akan memberikan implikasi positif terhadap penurunan manajemen laba akrual. Dari analisis dan temuan penelitian terdahulu, maka hipotesis pertama dirumuskan sebagai berikut.

\section{$\mathrm{H}_{1}$ : Beban pajak tangguhan berpe-ngaruh signifikan terhadap manajemen laba akrual.}

\section{Perencanaan Pajak Terhadap Manajemen Laba Akrual}

Perencanaan pajak merujuk kepada proses merekayasa usaha transaksi wajib pajak agar utang pajak berada dalam jumlah yang minimal, tetapi masih dalam bingkai peraturan perpajakan. Jadi dengan melakukan perencanaan pajak, perusahaan dapat memperkecil jumlah laba perusahaan untuk dapat memperoleh keuntungan pajak tanpa melakukan pelanggaran terhadap UU perpajakan yang berlaku.

Sumomba dan Hutomo (2012) dalam penelitiannya menarik kesimpulan bahwa perencanaan pajak dapat digunakan untuk mendeteksi manajemen laba, hal ini disebabkan manajemen selalu merespon perubahan tarif pajak, baik itu kenaikan tarif pajak atau penurunan tarif pajak yang dianggap oleh manajemen sebagai peluang "emas" untuk memberikan profit bagi perusahaan baik pada periode tersebut maupun periode yang akan datang.

Berdasarkan dari teori akuntansi positif dan beberapa hasil penelitian diatas maka dapat diasumsikan bahwa dengan adanya perencanaan pajak akan memberikan implikasi positif terhadap penurunan manajemen laba akrual. Dari analisis dan temuan penelitian terdahulu, maka 
hipotesis kedua dirumuskan sebagai berikut.

\section{$\mathrm{H}_{2}$ : Perencanaan Pajak berpengaruh signifikan terhadap manajemen laba akrual.}

\section{Kepemilikan Manajerial Terhadap Manaje- men Laba Akrual}

Kepemilikan manajerial merupakan jumlah saham yang dimiliki oleh pihak manajemen perusahaan, yang berarti pihak manajemen juga bertindak sebagai pemegang saham atas perusahaan yang dikelolanya. Oleh sebab itu pihak manajemen juga bertindak sebagai pemegang saham perusahaannya sendiri, maka dapat diperkirakan manajer akan mengambil langkah yang sejalan dengan apa yang diinginkan sebagai pemegang saham, yaitu ingin merasakan manfaat dari setiap keputusan yang diambil.

Menurut Syafrudin (2006) yang diperkuat oleh Puspito (2011) pengaruh struktur kepemilikan perusahaan pada kinerja perusahaan dengan struktur modal sebagai pemoderasi bahwa penelitian ini memberikan bukti variabel struktur kepemilikan oleh manajer tidak berpengaruh terhadap kinerja perusahaan.

Berdasarkan dari teori agency dan beberapa hasil penelitian diatas maka dapat diasumsikan bahwa dengan adanya kepemilikan manajerial akan memberikan implikasi positif terhadap penurunan manajemen laba akrual.

Berdasarkan analisis dan temuan penelitian terdahulu, maka hipotesis ketiga dirumuskan sebagai berikut.

\section{$\mathrm{H}_{3}$ : Kepemilikan manajerial tidak ber- pengaruh signifikan terhadap mana- jemen laba akrual.}

Pengaruh Beban pajak tangguhan yang dimoderasi kepemilikan institusional terhadap manajemen laba akrual.

Kepemilikan institusional memiliki arti penting dalam memonitor manajemen. Adanya kepemilikan oleh institusional akan mendorong peningkatan pengawasan yang lebih optimal, Sumanto dan Kiswanto (2014). Jika terjadi pengawasan mengenai kinerja perusahaan, maka akan menekan manajer dalam melakukan tindakan mana-jemen laba dan perusahaan dalam mela-kukan manajemen laba dengan diskresi akrual yang susuai dengan PSAK dan ketentuan perpajakan. Dengan kepemilikan institusional yang tinggi akan menimbulkan usaha pengawasan yang lebih besar oleh pihak investor institutional sehingga dapat menghalangi perilaku oportunistik manajer.

Berdasarkan dari teori akuntansi positif dan beberapa hasil penelitian diatas maka dapat diasumsikan bahwa dengan adanya beban pajak tangguhan akan memberikan implikasi positif terhadap penurunan manajemen laba akrual.

Dari analisis dan temuan penelitian terdahulu, maka hipotesis keempat dirumuskan sebagai berikut.

\section{$\mathrm{H}_{4}$ : Kepemilikan institusional memo-derasi hubungan kausalitas antara beban pajak tangguhan terhadap manajemen laba akrual.}

Pengaruh perencanaan pajak yang dimoderasi kepemilikan institusional terhadap manajemen laba akrual.

Perencanaan pajak merupakan langkah awal dimana melakukan pengumpulan data dan penelitian sehingga menjadi laporan yang sesuai dan transparan dengan tidak meninggalkan peraturan-peraturan perpajakan, dengan maksud agar tidak terjadi kesalahan atau penyalahgunaan dalam perencanaan pajak. Mempertimbangkan output dan input itu sangatlah penting karena tujuannya agar memaksimalkan keuntungan atau nilai perusahaan tersebut dengan mempertimbangkan perilaku manajerial, biaya keagenan, dan struktur kepemilikan dalam perusahaan dengan memadukan keterbatasan kondisi-kondisi yang relevan, Jensen dan Meckling (1976).

Penelitian yang berhubungan dengan faktorfaktor manajemen laba akrual, khususnya yang mengunakan variabel moderasi telah dilakukan oleh beberapa peneliti, diantaranya oleh Sartika 
dan Fidiana (2015) yaitu perencanaan pajak dengan kepemilikan institusional mampu memoderasi dan berpengaruh positif terhadap nilai perusahaan. Peneliti Kusumayani dan Suardana (2017) dengan variabel moderasi kepemilikan manajerial dan kepemilikan institusional.

Berdasarkan dari teori akuntansi positif dan beberapa hasil penelitian diatas maka dapat diasumsikan bahwa dengan adanya perencanaan pajak akan memberikan implikasi positif terhadap penurunan manajemen laba akrual. Dari analisis dan temuan penelitian terdahulu, maka hipotesis kelima dirumuskan sebagai berikut.

\section{$\mathrm{H}_{5}$ : Kepemilikan institusional memo-derasi hubungan kausalitas antara perencanaan pajak terhadap manajemen laba akrual.}

Pengaruh Kepemilikan manajerial yang dimoderasi kepemilikan institusional terhadap manajemen laba akrual.

Kepemilikan manajerial adalah kepemilikan saham perusahaan oleh pihak manajemen. Kepemilikan saham perusahaan oleh manajemen dapat menurunkan keinginan manajemen dalam mendapatkan kemak-muran dengan mempertinggi pendapatan dari tingginya tingkat laba perusahaan dengan harapan mendapatkan bonus yang besar, Yunianto (2016). Dengan kepemilikan institusional sebagai pengawasan dalam perusahaan yang dipimmpin oleh manajemen perusahaan dalam melakukan manajemen laba akrual sama- sama memiliki motivasi yang sama dalam menaikan laba.

Hasil penelitian-penelitian tersebut selaras dengan penelitian Jensen dan Meckling (1976) yang menyatakan bahwa kepemilikan manajerial berhasil menjadi mekanisme untuk mengurangi masalah keagenan dari manajer dengan menyelaraskan kepentingan-kepentingan manajer dengan pemegang saham. Semakin besar kepemilikan manajemen dalam perusahaan maka manajemen akan cenderung berusaha untuk meningkatkan kinerjanya, Siallagan dan Machfoedz (2006). Berdasarkan dari teori agency dan beberapa hasil penelitian diatas maka dapat diasumsikan bahwa dengan adanya kepemilikan manajerial akan memberikan implikasi positif terhadap penurunan manajemen laba akrual.

Motivasi peneliti dalam penelitian ini menggunakan kepemilikan institusional sebagai variabel moderasi. Berdasarkan analisis dan temuan penelitian terdahulu, maka hipotesis keenam dirumuskan sebagai berikut.

$\mathrm{H}_{6}$ : Kepemilikan institusional memo-derasi hubungan kausalitas antara kepemilikan manajerial terhadap manajemen laba akrual.

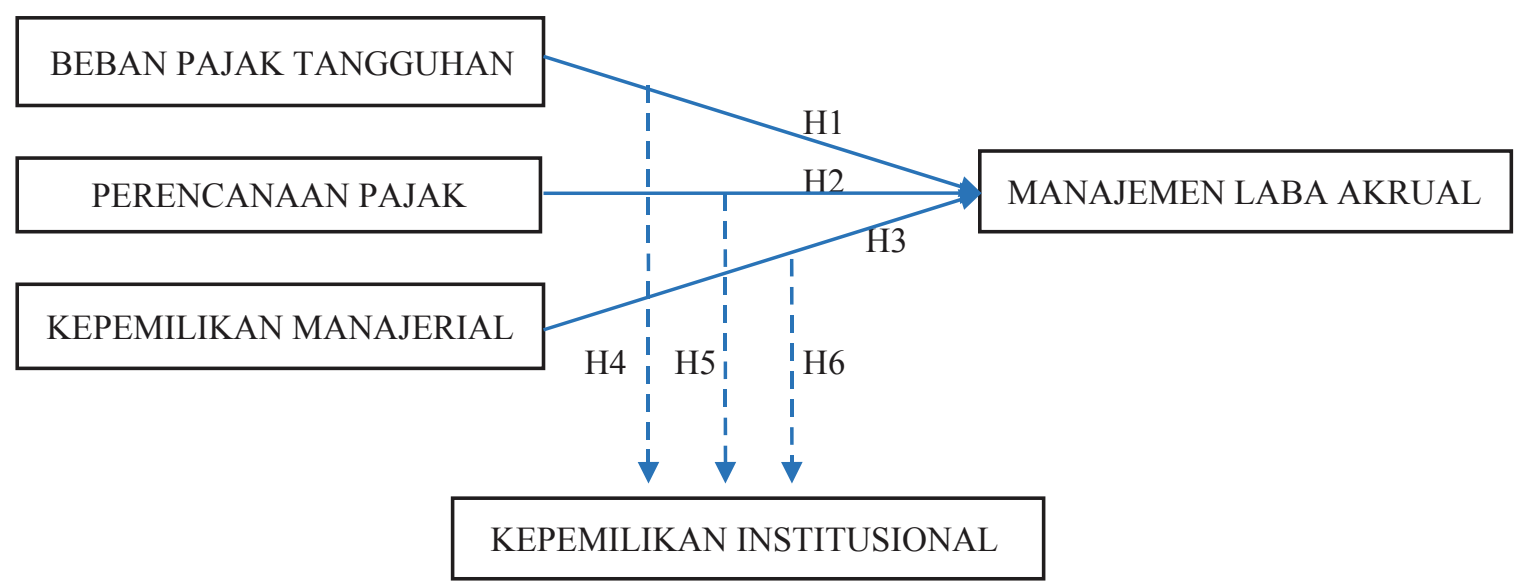

Gambar 1. Paradigma Penelitian 


\section{Metode}

Metode penelitian yang digunakan dalam penelitian ini adalah explanatory survey. Metode ini bertujuan untuk menguji hipotesis, yang umumnya merupakan penelitian yang menjelaskan fenomena dalam bentuk hubungan antar variabel.

Populasi dalam penelitian ini adalah perusahaan-perusahaan pertambangan sektor minyak dan gas bumi yang terdaftar di Bursa Efek Indonesia dari tahun 2011 sampai 2015. Dalam penelitian ini yang dimaksud populasi adalah laporan keuangan sebanyak 45 laporan keuangan perusahaan (Emiten) pertambangan sektor minyak dan gas bumi yang terdaftar di Bursa Efek Indonesia. Dalam penelitian ini, setelah data diperoleh dengan kriteria tertentu maka untuk mengolah data tersebut menggunakan analisis regresi moderasi (moderated regression analysis). Moderated regression analysis (MRA) yaitu aplikasi khusus regresi linear berganda dimana mengandung interaksi persamaan regresi (perkalian dua atau lebih variabel independen).

Persamaan dari model regresi tersebut dituliskan sebagai berikut:

$$
\begin{aligned}
\boldsymbol{Y}= & a+b_{1} X_{1}+b_{2} X_{2}+b_{3} X_{3}+b_{4} X_{1} * X_{4}+b_{5} X_{2} \\
& * X_{4}+b_{6} X_{3} * X_{4} e
\end{aligned}
$$

Keterangan:

$$
\begin{aligned}
\mathrm{Y}= & \text { Manajemen Laba } \\
\mathrm{a} & =\text { konstanta } \\
\mathrm{b}= & \text { koefisien regresi } \\
\mathrm{X}_{1}= & \text { Beban Pajak Tangguhan } \\
\mathrm{X}_{2}= & \text { Perencanaan Pajak } \\
\mathrm{X}_{3}= & \text { Kepemilikan Manajerial } \\
\mathrm{X}_{4}= & \text { Kepemilikan Institusional sebagai } \\
& \text { pemoderasi } \\
e= & \text { error }
\end{aligned}
$$

Perhitungan akrual diawali dengan perhitungan total akrual. Total akrual adalah selisih antara laba dan arus kas yang berasal dari aktivitas operasi. Sahabu (2009) total akrual dapat dibedakan menjadi dua bagian, yaitu:
1. Bagian akrual yang memang sewajarnya ada dalam proses penyusunan laporan keuangan, disebut normal accruals atau non-discretionary accruals.

2. Bagian akrual yang merupakan manipulasi data akuntansi yang disebut dengan abnormal accruals atau discretionary accruals.

Penelitian ini mengunakan discretionary accrual dengan modified Jones yang dimodifikasi oleh Kothari et al. (2005).

$$
\begin{aligned}
\text { TAC }_{\mathrm{it}}= & \alpha_{0}\left(\mathbf{1}_{\mathrm{AAsset}}-1\right)+\beta_{1}\left[\left(\Delta \text { Sales }_{\mathrm{it}}-\Delta \operatorname{Rec}_{\mathrm{it}}\right)\right. \\
& \left./ \text { Asset }_{\mathrm{it}}-1\right]+\beta_{2}\left(\mathrm{PPE}_{\mathrm{it}} / \text { Asset }_{\mathrm{it}}-1\right)+\beta_{3} \\
& \operatorname{ROA}_{\mathrm{it}}-1+\varepsilon_{\mathrm{it}}
\end{aligned}
$$

Keterangan:

$\mathrm{Tac}_{\mathrm{it}}=$ Total accruals perusahaan i pada tahun $\mathrm{t}$

Asset $_{\mathrm{it}}-1=$ Logaritma total aset perusahaan i pada tahun $\mathrm{t}-1$

$\Delta$ Sales $_{\text {it }}=$ Perubahan penjualan perusahaan $\mathrm{i}$ pada tahun $\mathrm{t}$ dengan tahun $\mathrm{t}-1$

$\Delta \mathrm{ARec}_{i \mathrm{it}}=$ Perubahan piutang dagang perusahaan $\mathrm{i}$ pada tahun $\mathrm{t}$ dengan tahun $\mathrm{t}-1$

$\mathrm{PPE}_{\mathrm{it}}=$ Nilai perolehan aktiva tetap pada perusahaan i pada tahun $\mathrm{t}$

$\mathrm{ROA}_{\mathrm{it}-1}=$ Rasio Return On Asset pada perusahaan i pada tahun t-1

$\Delta \beta_{1} \beta_{2}=$ Estimasi non-discretionary accruals

$\varepsilon_{\mathrm{it}} \quad=\quad$ error term

Total accruals pada model tersebut berasal dari perhitungan:

$$
\text { TAC }_{i t}=\text { Operating Income }_{i t}-\mathrm{CFO}_{\mathrm{it}}
$$

Keterangan:

$\mathrm{TAC}_{\mathrm{it}}=$ Total accruals perusahaan i pada tahun $\mathrm{t}$

$\mathrm{CFO}_{\text {it }}=$ Logaritma total aset perusahaan $\mathrm{i}$ pada tahun $\mathrm{t}-1$

Non Discretionary Accrual (NDAC) merupakan nilai prediksi atau fitted value dari model diatas, dan Discretionary Accrual (DAC) merupakan selisih dari Total Accrual (TAC) 
dengan Non Discretionary Accrual (NDAC). Berikut adalah perhitungan tersebut:

$$
\text { DAC }_{i t}=\text { TAC }_{i t}-\text { NDAC }_{i t}
$$

Keterangan:

$\mathrm{DAC}_{\mathrm{it}}=$ Discretionary Accrual perusahaan i pada tahun $\mathrm{t}$

$\mathrm{TAC}_{\mathrm{it}}=$ Total accruals perusahaan i pada tahun $\mathrm{t}$

$\mathrm{NDAC}_{\mathrm{it}}=$ Non Discretionary Accrual i pada tahun $\mathrm{t}$

Beban pajak tangguhan adalah beban yang timbul akibat perbedaan temporer antara laba akuntansi (yaitu laba dalam laporan keuangan untuk kepentingan pihak eksternal) dengan laba fiskal (laba yang digunakan sebagai dasar perhitungan pajak). Pengukuran Perencanaan Pajak dapat dilakukan dengan rumus sebagai berikut menurut Wijaya dan Martani (2011) :

Keterangan :

TAX PLAN $=\frac{\sum_{t}^{t-1}\left(\boldsymbol{T P}_{\boldsymbol{t}} \cdot P T I-C T E\right) / 3}{\boldsymbol{T} \boldsymbol{A}_{\boldsymbol{t}}}$

TAX PLAN : Perencanaan pajak

PTI : Pre-tax income (pendapatan sebelum kena pajak)

CTE : Current portion of total tax expence (beban pajak kini)

TP : Tarif pajak

TA : Total asset

Kepemilikan manajemen adalah persentase kepemilikan saham oleh direksi, manajemen, komisaris maupun setiap pihak yang terlibat secara langsung dalam pembuatan keputusan perusahaan menurut Diyah dan Erman (2009).

\section{$K M=\frac{\text { Jumlah Saham Manajemen }}{\text { Jumlah Saham yang Beredar }}$}

Kepemilikan institusi menunjukan jumlah persentase saham yang dimiliki oleh institusi/ lembaga atau masyarakat umum yang kepemilikan sahamnya diatas $5 \%$. Variabel ini diukur dari penjumlahan atas persentase saham perusahaan lain baik yang berada di dalam maupun di luar negeri serta saham pemerintah baik di dalam maupun di luar negeri (Nurhidayati, 2013).

\section{$K I=\frac{\text { Jumlah Saham Institusi }}{\text { Jumlah Saham yang Beredar }}$}

\section{Hasil Penelitian dan Pembahasan}

Data yang digunakan dalam penelitian ini adalah data sekunder yang diperoleh dari Bursa Efek Indonesia. Populasi dalam penelitian ini adalah perusahaan yang masuk kedalam kelompok perusahaan pertambangan sektor minyak dan gas.

Perusahaan yang dijadikan sampel adalah perusahaan yang terdaftar di Bursa Efek Indonesia dan termasuk kedalam kelompok perusahaan pertambangan sektor minyak dan gas selama 5 tahun berturut-turut dari tahun 2011 sampai dengan tahun 2015. Berdasarkan kriteria maka jumlah pengamatan didalam penelitian ini berjumlah 43 pengamatan.

Model regresi akan dinyatakan baik dan dapat dilakukan jika memenuhi uji asumsi klasik yaitu uji normalitas, uji multikolonearitas, uji autokorelasi dan uji heteroskedastisitas. Dan penelitian ini telah memenuhi uji asumsi klasik, seperti dalam table berikut ini: 
Tabel 1. Ringkasan Uji Asumsi Klasik Atas Pengujian Hipotesis Beban Pajak Tangguhan, Perencanaan Pajak, Kepemilikan Manajerial Dan Kapemilikan Institusional sebagai Pemoderasi Terhadap Manajemen Laba Akrual

\begin{tabular}{lrc}
\hline Variabel Bebas dan Moderasi & & \\
\hline Pengujian Multikolonieritas & Toleran & VIF \\
\hline Beban Pajak Tangguhan & 0.529 & 1.892 \\
Perencanaan Pajak & 0.892 & 1.121 \\
\hline Kepemilikan Institusional & 0.947 & 1.056 \\
Beban Pajak Tangguhan*Kepemilikan Institusional & 0.671 & 1.490 \\
Perencanaan Pajak*Kepemilikan Institusional & 0.842 & 1.188 \\
Kepemilikan Manajerial*Kepemilikan Institusional & 0.644 & 1.552 \\
\hline Pengujian Heterokedastisitas (Glejser test) & Sig. t-test & \\
\hline Beban Pajak Tangguhan & 0.798 \\
Perencanaan Pajak & -1.372 & \\
Kepemilikan Institusional & 1.723 & \\
Beban Pajak Tangguhan*Kepemilikan Institusional & -0.278 & \\
Perencanaan Pajak*Kepemilikan Institusional & 0.324 & \\
Kepemilikan Manajerial*Kepemilikan Institusional & -2.032 & \\
\hline Durbin-Watson test & 2,113 & \\
\hline e Kolmogorov-Smirnov test & 0,164 & \\
N = 43 & & \\
\hline
\end{tabular}

Sumber: Output SPSS

Tabel 2. Ringkasan Pengujian Hipotesis Beban Pajak Tangguhan, Perencanaan Pajak, Kepemilikan Manajerial Dan Kapemilikan Institusional sebagai Pemoderasi Terhadap Manajemen Laba Akrual

\begin{tabular}{lrrr}
\hline Variabel Bebas dan Moderasi & & & \\
\hline Pengujian hipotesis & Coefficient & t value & \multicolumn{1}{c}{ Sign } \\
\hline Beban Pajak Tangguhan & 0,153 & 0,829 & 0,413 \\
Perencanaan Pajak & 0,228 & 1,603 & 0,118 \\
Kepemilikan Institusional & 0,012 & 0,089 & 0,930 \\
Beban Pajak Tangguhan*Kepemilikan Institusional & 0,337 & 2,053 & $0,047^{*}$ \\
Perencanaan Pajak*Kepemilikan Institusional & 0,009 & 0,060 & 0,952 \\
Kepemilikan Manajerial*Kepemilikan Institusional & $-0,489$ & $-2,920$ & $0,006^{*}$ \\
\hline R square & 0,349 & & \\
Adjust $R$ square & 0,240 & & \\
F statistik & 3,216 & & \\
Signifikan F statistik & 0,012 & & \\
\hline Variabel trikat : Manajemen Laba Akrual & & & \\
N = 43 & & & \\
*Tingkat signifikan 5\% & & & \\
\hline Sumber: Output SPSS & & & \\
& & & \\
\end{tabular}




\section{Pengaruh beban pajak tangguhan terhadap manajemen laba akrual}

Berdasarkan hasil penelitian yang telah dilakukan dengan analisa regresi berganda dengan hasil hipotesis pertama yang menunjukkan bahwa beban pajak tangguhan tidak berpengaruh terhadap manajemen laba akrual, hal tersebut sesuai dengan pernyataan pada hipotesis pertama. Dengan adanya kebijakan akrual tidak mempengaruhi manajemen dalam melakukan manipulasi laba. Hal ini bertentangan dengan hipotesis dan berarti bahwa perusahaan yang dijadikan sampel telah sesuai melaporkan beban pajak tangguhan tanpa melakukan rekayasa dalam upaya untuk meminimalkan pajak. Hal ini juga mencerminkan bahwa perusahaan yang dijadikan sampel telah benar menerapkan metode akuntansi tanpa melakukan upaya manajemen laba akrual.

Hasil penelitian ini bertentangan dengan penelitian sebelumnya yang telah dilakukan oleh Yulianti (2005), Abdul Rafay and Mobeen Ajmal (2014), Hakim dan Praptoyo (2015), Philip et al. (2003), dan Yana Ulfa (2013) yang menyatakan bahwa beban pajak tangguhan berpengaruh signifikan terhadap manajemen laba. Namun penelitian ini sejalan dengan penelitian yang sebelumnya dilakukan oleh Fitriany (2016), Amanda dan Febrianti (2015), Utari dan Widiastuti (2013) menunjukkan bahwa beban pajak tangguhan tidak berpengaruh signifikan terhadap manajemen laba.

\section{Pengaruh perencanaan pajak (tax planning) terhadap manajemen laba akrual}

Berdasarkan hasil hipotesis dari analisa regresi berganda yang menunjukkan bahwa perencanaan pajak tidak berpengaruh terhadap manajemen laba akrual, hal tersebut sesuai dengan pernyataan pada hipotesis kedua. Hal tersebut berdasarkan semakin rendah perencanaan pajak maka semakin kecil peluang perusahaan melalukan manajemen laba. Hal ini bertentangan dengan hipotesis dan berarti bahwa perusahaan melakukan perencanaan pajak itu sendiri merupakan sarana untuk memenuhi kewajiban perpajakan dengan benar, tetapi jumlah pajak yang dibayarkan dapat ditekan seminimal mungkin untuk memperoleh laba yang diharapkan. Salah satu perencanaan pajak adalah dengan cara mengatur seberapa besar laba yang dilaporkan, sehingga masuk dalam indikasi adanya praktik manajemen laba.

Strategi penghematan pajak yang dilakukan oleh perusahaan haruslah bersifat legal untuk menghindari pengenaan sanksi-sanksi pajak di kemudian hari. Penghematan pajak akan selalu menganut prinsip "the least and latest".

Perusahaan yang dijadikan sampel telah sesuai menerapkan perencanaan pajak tanpa melakukan rekayasa dalam upaya untuk maminimalkan pajak. Hal ini juga mencerminkan bahwa perusahaan yang dijadikan sampel telah benar menerapkan metode perencanaan pajak yang sesuai dengan peraturan yang berlaku tanpa melakukan upaya manajemen laba akrual.

Hasil penelitian ini bertentangan dengan penelitian sebelumnya yang telah dilakukan oleh Santana dan Wirakusuma (2016), Sumomba dan Hutomo (2012), Anggreani (2013) yang menyatakan bahwa perencanaan pajak berpengaruh signifikan terhadap manajemen laba. Namun penelitian ini sejalan dengan penelitian yang sebelumnya dilakukan oleh Aditama dan Purwaningsih (2016) menunjukkan bahwa perencanaan pajak tidak berpengaruh signifikan terhadap manajemen laba.

\section{Pengaruh beban pajak tangguhan terhadap manajemen laba akrual ketika dimoderasi oleh kepemilikan Institusional.}

Berdasarkan hasil penelitian yang telah dilakukan dengan analisa regresiberganda dengan hasil hipotesis keempat yang menunjukkan bahwa beban pajak tangguhan berpengaruh signifikan terhadap manajemen laba akrual ketika dimoderasi oleh kepemilikan institusional, hal tersebut sesuai dengan pernyataan pada hipotesis keempat. Diskresi akrual yang dilakukan oleh perusahaan ketika diperkuat oleh kepemilikan 
institusional membawa pengaruh terhadap manajemen laba. Hal ini sesuai dengan hipotesis dan berarti bahwa perusahaan yang dijadikan sampel telah melaporkan beban pajak tangguhan dan melakukan rekayasa dalam upaya untuk meminimalkan pajak. Oleh karena itu dengan adanya kepemilikan institusional manajemen masih bisa melakukan manipulasi laba.

Dengan terbuktinya beban pajak tangguhan berpengaruh signifikan terhadap manajemen laba karena beban pajak tangguhan dapat mendeteksi perusahaan dalam melakukan manajemen laba ketika dimoderasi oleh kepemilikan institusional. Karena bila perusahaan menurunkan labanya pengaruhnya terhadap beban pajak tangguhan kecil sehingga bila ingin mendeteksi manajemen laba dalam perusahaan melalui beban pajak tangguhan cukup efektif karena beban pajak tangguhan masih dapat menggambarkan bahwa perusahaan tersebut melakukan manajemen laba akrual.

\section{Pengaruh perencanaan pajak terhadap manajemen laba akrual ketika dimoderasi oleh kepemilikan Institusional.}

Berdasarkan hasil penelitian yang telah dilakukan dengan analisa regresi berganda dengan hasil hipotesis kelima yang menunjukkan bahwa perencanaan pajak tidak berpengaruh signifikan terhadap manajemen laba akrual ketika dimoderasi oleh kepemilikan institusional, pernyataan tersebut sesuai dengan pernyataan pada hipotesis kelima. Hal tersebut berdasarkan semakin rendah perencanaan pajak maka semakin kecil peluang perusahaan melalukan manajemen laba. Hal ini bertentangan dengan hipotesis dan berarti bahwa perusahaan yang dijadikan sampel telah sesuai melakukan perencanaan pajak tanpa melakukan rekayasa dalam upaya untuk meminimalkan pajak. Oleh karena itu dengan adanya pengawasan dari kepemilikan institusional agar manajemen tidak melakukan manipulasi laba. Dengan terbuktinya perencanaan pajak tidak berpengaruh signifikan terhadap manajemen laba karena perencanaan pajak tidak dapat mendeteksi perusahaan dalam melakukan manajemen laba. Tujuan lain manajemen melakukan manajemen laba melalui perencanaan pajak adalah untuk meminimalkan beban PPh supaya perusahaan membayar pajak serendah mungkin, hal tersebut tidak terbukti adanya perencanaan pajak untuk tujuan manajemen laba.

Hal ini mencerminkan bahwa perusahaan pertambangan sektor minyak dan gas yang dijadikan sampel telah benar menerapkan metode pembayaran pajak sesuai dengan peraturan perpajakan yang berlaku tanpa melakukan upaya manajemen laba. Hasil penelitian ini tidak sejalan dengan penelitian sebelumnya yang telah dilakukan oleh Kusumayani dan Suardana (2017) dengan variabel moderasi kepemilikan manajerial dan kepemilikan institusional.

\section{Pengaruh kepemilikan manajerial terhadap manajemen laba akrual ketika dimoderasi oleh kepemilikan Institusional.}

Berdasarkan hasil penelitian yang telah dilakukan dengan analisa regresi berganda dengan hasil hipotesis keenam yang menunjukkan bahwa kepemilikan manajerial berpengaruh signifikan terhadap manajemen laba akrual ketika dimoderasi oleh kepemilikan institusional, hal tersebut tidak sesuai dengan pernyataan pada hipotesis keenam. Kebijakankebijakan oleh manajemen yang merangkap sebagai pemegang saham semakin memperkuat pengaruhnya terhadap keputusan perusahaan (diskresi akrual) ketika dipengaruhi oleh pemegang saham corporate.

Kepemilikan manajemen merupakan proporsi pemegang saham dari pihak manajemen yang secara aktif ikut dalam pengambilan keputusan perusahaan (direktur dan komisaris). Kepemilikan oleh manajemen yang besar akan efektif memonitoring aktivitas perusahaan. Ketika kepemilikan saham oleh manajemen rendah maka ada kecenderungan akan terjadinya perilaku opportunistic manajer yang meningkat. Dengan adanya kepemilikan manajemen 
terhadap saham perusahaan maka dipandang dapat menyelaraskan potensi perbedaan kepentingan antara manajemen dan pemegang saham lainnya sehingga permasalahan antara agen dan principal diasumsikan akan hilang apabila seorang manajer juga sekaligus sebagai pemegang saham bisa mempengaruhi dalam pengambilan keputusan. Dengan terbuktinya kepemilikan manajerial berpengaruh signifikan terhadap manajemen laba dengan kepemilikan institusional sebagai pemoderasi tidak memberi dampak pengawasan terhadap manajemen dalam melakukan praktek manajemen laba.

Hasil penelitian ini sesuai dengan teori agency yang dikemukakan oleh (Jensen dan Meckling 1976) yang menyatakan bahwa peningkatan kepemilikan saham manajerial dapat menurunkan agency cost karena dapat mensejajarkan kepentingan dari pemilik dengan kepentingan para manajer.

\section{Simpulan, Keterbatasan, dan Implikasi Hasil Penelitian}

Beban pajak tangguhan tidak berpengaruh signifikan terhadap manajemen laba akrual pada perusahaan pertambangan sektor minyak dan gas bumi. Perusahaan pertambangan tidak memanfaatkan celah untuk memanipulasi laba dengan besarnya beban pajak tangguhan yang dimiliki. Hal ini dapat terjadi karena perusahaan pertambangan merupakan perusahaan dengan peraturan perpajakan khusus yang juga mendapat perhatian khusus dari regulator (Kementrian ESDM) sehingga tidak dapat memainkan angka beban pajak tangguhan untuk memanipulasi labanya seperti yang dilakukan oleh perusahaan lain pada umumnya

Perencanaan pajak tidak berpengaruh signifikan, semakin rendah perencanaan pajak maka semakin kecil peluang perusahaan melalukan manajemen laba. Perusahaan dalam melakukan perencanaan pajak sudah sesuai dengan peraturan perpajakan yang berlaku, hal ini perusahaan pertambangan tidak ada cara mengatur seberapa besar laba yang dilaporkan, sehingga tidak ada indikasi praktik manajemen laba.

Hasil penelitian ini membuktikan bahwa kepemilikan institusional memoderasi hubungan kausalitas antara beban pajak tangguhan terhadap manajemen laba akrual. Hasil dari penelitian ini berbeda dengan sebelum dimoderasi. Hal ini dapat terjadi karena beban pajak tangguhan ketika diperkuat oleh kepemilikan institusional membawa pengaruh terhadap manajemen untuk menaikan laba guna kepentingan para pemegang saham. Kepemilikan Institusional tidak memoderasi hubungan kausalitas antara perencanaan pajak terhadap manajemen laba akrual. Dengan adanya perencanaan pajak yang merupakan dari perencanaan anggaran perusahaan dengan pengawasan yang ketat dari regulator (Kementrian ESDM) sehingga tidak adanya celah bagi perusahaan dalam manipulasi pajak. Corporate stock holders sebagai kepemilikan institusional atas perusahaan tidak mampu mempengaruhi keputusan-keputusan manajemen terkait kebijakan akrual untuk melakukan manajemen laba. Kepemilikan institusional memoderasi hubungan kausalitas antara kepemilikan manajerial terhadap manajemen laba akrual. Kebijakan-kebijakan oleh manajemen yang merangkap sebagai pemegang saham semakin memperkuat pengaruhnya terhadap keputusan perusahaan (diskresi akrual) ketika dipengaruhi oleh pemegang saham corporate (kepemilikan institusional.)

Meskipun penelitian ini sudah menggunakan teknik yang sejalan dengan prosedur penelitian, namun masih keterbatasan dimana penelitian ini hanya mengambil populasi dan sampel pada perusahaan-perusahaan pertambangan sektor minyak dan gas bumi di Bursa Efek Indonesia pada periode tahun 2011 sampai tahun 2015. Dengan pendeknya periode penelitian dan jumlah data yang terbatas tersebut, maka hasilnya pun terlihat kurang optimal. Teori yang masih sangat minim dan belum begitu banyak penelitian yang menguji hubungan ini, sehingga peneliti 
mengalami keterbatasan dalam menginterpretasi hasil penelitian.

Hasil uji determinasi dapat diketahui nilai Adjusted $R$ Square adalah sebesar 0,240 atau $24 \%$ sedangkan sisanya sebesar $76 \%$ dipengaruhi atau dijelaskan oleh variabel lain yang tidak dimasukkan dalam model penelitian. Dengan merujuk hasil tersebut dapat menggambarkan bahwa model analisis regresi moderasi dalam penelitian ini kurang mendukung untuk hasil penelitian yang optimal. Hal tersebut disebabkan jumlah perusahaan pertambangan sektor minyak dan gas bumi yang terdaftar di Bursa Efek Indonesia pada periode penelitian jumlahnya sedikit. Selain dari pada itu, variabel yang digunakan dalam penelitian ini hanya mengggunakan tiga variabel independen dan satu variabel moderasi saja, sehingga hasil penelitian tidak dapat menggambarkan situasi secara keseluruhan. Namun, hasil penelitian ini sejalan dengan hasil penelitian-penelitian sebelumnya yang mana hasil uji determinasinya memiliki nilai Adjusted R Square yang kecil.

Penelitian ini diharapkan dapat memberikan tambahan referensi kepustakaan bidang perpajakan untuk dilakukan penelitian kembali dengan variabel-variabel yang berbeda. Seperti menambahkan variabel independen atau mengganti variabel moderasi lain seperti non debt tax shields atau good corporate governance $(G C G)$. Sedangkan untuk peneliti selanjutnya menggunakan perbandingan sampel dengan sektor lain atau lebih berbeda lagi dengan perusahaan manufaktur agar dapat memberikan gambaran yang jelas dan kontribusi informasi yang lebih luas terhadap prospek perusahaan di Indonesia dengan kondisi regulasi dan iklim investasi yang berlaku saat ini.

Hasil penelitian menunjukan bahwa hasilnya tidak berpengaruh terhadap manajemen laba akrual, hal ini menunjukan bahwa kinerja dari manajemen telah sesuai dengan prinsipprinsip akuntable dan responsible yang merupakan bentuk pengelolaan keuangan berdasarkan prinsip yang dianut good corporate governance (GCG). Peneliti menyarankan agar prinsip-prinsip ini sebagai pedoman untuk praktisi (manajemen perusahaan pertambangan sektor minyak dan gas). Hasil penelitian ini dapat digunakan sebagai informasi mengenai hal-hal yang berpengaruh signifikan terhadap manajemen laba yang dapat dipergunakan sebagai bahan pertimbangan dalam faktor perpajakan dan kepemilikan saham di perusahaan yang go public.

\section{Daftar Referensi}

Aditama, Ferry dan Purwaningsih Anna. 2016. Pengaruh Perencanaan Pajak terhadap Manajemen Laba pada Perusahaan Non Manufaktur yang Terdaftar di Bursa Efek Indonesia. Jurnal Ekonomi Universitas Atma Jaya, Yogyakarta.

Agusti Restu dan Tyas Pramesti, 2009. Pengaruh Asimetri Informasi, Ukuran Perusahaan dan Kepemilikan Manajerial Terhadap Manajemen Laba. Jurnal Ekonomi Unri ISSN 0853-7593. Vol 17, No 01.

Amertha Indra Satya Prasavita 2013. Pengaruh Return On Asset Pada Praktik Manajemen Laba Dengan Moderasi Corporate Governance. E-Jurnal Akuntansi Universitas Udayana 4.2(2013):373-387. ISSN 2302-8556

Arles.P. Ompusunggu 2011, buku Cara Legal Siasati Pajak. Depok. Penerbit Puspa swara. Aziz, Muhammad Fahmi. 2015 Pengaruh Beban Pajak Tangguhan dan Profitabilitas Terhadap Praktik Manajemen Laba. Jurnal Akuntansi Universitas Gunadarma

Bursa Efek Indonesia. http://www.idx. co.id/id-id/beranda/perusahaantercatat/ laporankeuangandantahunan.aspx. Diakses: Minggu, 3 september 2016

Catherine. 2013. Pengaruh Dewan Komisaris Independen, Komite Audit, Kepemilikan Manajerial dan Kualitas Audit terhadap Perataan Laba. Jurnal Akuntansi, Vol. 7, No. 2, Mei 2014. 
Diyah, P dan W. Erman. 2009.Pengaruh Struktur Kepemilikan Terhadap Nilai Perusahaan Keputusan Keuangan sebagai Variabel Intervening. Jurnal Ekonomi Bisnis dan Akuntansi Ventura 2(1): 71-86.

Djaddang, Syahril. 2016. Determinan Manajemen Akrual dan Volatilitas Laba Pada Perusahaan Hedgers and Unhedgers (Perspektif Opportunistik dan Kontrak Efisien). Pustaka Magister Universitas Diponegoro Semarang.

Fitriany, Lucy Citra, 2016. Pengaruh Aset Pajak Tangguhan, Beban Pajak Tangguhan dan perencanaan Pajak Terhadap Manajemen Laba. Jurnal Ekonomi Universitas Riau. Vol.3 No.1

Gumanti, Tatang Ary. (2000). Earnings Management: Suatu Telaah Pustaka. Jurnal akuntansi dan Keuangan. Vol. 2 No. 2.

Ghozali, Imam. 2013. Aplikasi Analisis Multivariate dengan program SPSS. Edisi Ketujuh. Semarang: Badan Penerbit Universitas Diponegoro.

Haruman, T. 2008. Pengaruh Struktur Kepemilikan Terhadap Keputusan Keuangan dan Nilai Perusahaan. Simposium Nasional Akuntansi XI Pontianak.

Healy, P. M. and Wahlen, J. M. 1999. "A Review of the Earnings Management Literature and Its Implications for Standard Setting”. Accounting Horizons 13 (4). December : 365 -383 .

Jensen, Michael C. dan W.H. Meckling. 1976. "Theory of the Firm:Managerial Behavior, Agency Cost and Ownership Structure."Journal of Financial Economics 3: 305--360.

Kothari, S.P., A. Leone, dan C. Wasley. 2005. PerformanceMatchediscretionaryAccruals. Journal of Accounting and Economics 39 (1).

Kusumayani, H. A. dan Suardana, K. A. 2017. Kepemilikan Manajerial dan Kepemilikan Institusional sebagai Pemoderasi Pengaruh Perencanaan Pajak Pada Niliai Perusahaan.
E-Jurnal Akuntansi Universitas Udayana Vol.18.1 January (2017):646-673. ISSN: 2302-8556.

Muid, Dul. 2009. Pengaruh Mekanisma Corporate Governance Terhadap Kualitas Laba. Jurnal Akuntansi. Vol. 4, No. 2, Hal: 94-108.

Made Sukartha, Pengaruh Manajemen Laba, Kepemilikan Manajerial dan Ukuran Perusahaan Pada Kesejahteraan Pemegang Saham Perusahaan Target Akuisisi, Jurnal Riset Akuntansi, Vol.10, No.3, September 2008.

Nugroho, Satria dan Darsono. 2015. Pengaruh Kompensasi, Kepemilikan Manajerial, Diversifikasi Perusahaan dan Ukuran KAP Terhadap Manajemen Laba. E-Jurnal Universitas Diponegoro.

Philips, Pincus dan S.O. Rego. 2003. Earnings Mangement :New Evidence Based on Deferred Tax Expensell. The Accounting Review. No. 78 pp 491- 521.

Scott, William R. 2000. Financial Accounting Theory. Second Edition. New Jersey: Prentice-Hall, Inc.

Scott, William R. 2003.Financial Accounting Theory 3rd Edision. Prentice Hall, Canada Inc.

Suandy. Erly, 2008. Hukum Pajak,edisi 4. Jakarta: Salemba Empat.

Suandy. Erly, 2011. Perencanaa Pajak,edisi 5. Jakarta: Salemba Empat.

Supriyadi. Edy. 2014. SPSS + AMOS Statistical Data Analysis, edisi 2. Jakarta: In Media

Siallagan, H. dan M. Machfoedz. 2006. Mekanisme Corporate Governance, Kualitas Laba dan Nilai Perusahaan. Simposium Nasional Akuntansi IX. Padang.23-26 Agustus 2006.

Santana dan Wirakusuma 2016. Pengaruh Perencanaan Pajak, Kepemilikan Manajerial dan Ukuran Perusahaan terhadap Praktek Manajemen Laba. E-Jurnal Akuntansi Universitas Udayana. 14 (3). Hal: 15551583. 
Sartika Dewi dan Fidiana 2015. Moderasi Kepemilikan Institusional Terhadap Hubungan Perencanaan Pajak Nilai Perusahaan. Jurnal Ilmu dan Riset Akuntansi STESIA Vol. 4 No.12 (2015).

Sumomba, Ranty Christina. 2012. Pengaruh Beban Pajak Tangguhan dan Perencanaan Pajak terhadap Manajemen Laba. Jurnal Bisnis dan Ekonomi,Vol.16 (No.2), hal 103115.

Sugiyono, 2010. Statistik Untuk Penelitian. Cetakan Enambelas. Bandung : Alfabeta

Sulistyanto, H. Sri. 2008. Manajemen Laba, Teori dan Model Empiris. Penerbit Grasindo, Jakarta.

Sahabu, Supardi, (2009)."Manajemen laba melalui Akrual Nyata dan Pengaruhnya terhadap Kinerja Jangka PanjangPerusahaan yang melakukan Penawaran Right Issue". Tesis YPKN.
Ulfah, Yana. 2013. Pengaruh Beban Pajak Tangguhan dan Perencanaan Pajak Terhadap Praktik Manajemen Laba. Prosiding Simposium Nasional Perpajakan 4.

Yudanto Tri D. dan Ratnaningsih D 2013. Pengaruh Struktur Kepemilikan Institusional dan Ukuran Perusahaan Sebagai Variabel Moderasi Terhadap Tipe Manajemen Laba Efisien atau Oportunistik. Jurnal Universitas Atma Jaya Yogyakarta.

Yulianti. 2005. Kemampuan Beban Pajak Tangguhan Mendeteksi Manajemen Laba. . Jurnal Akuntansi dan Keuangan Indonesia.

Waluyo. 2014. Akuntansi Pajak. Jakarta: Salemba Empat.

Wiryandari, Santi Aryn \& Yulianti, 2009. Hubungan Perbedaan Laba Akuntansi \& Laba Pajak Dengan Perilaku Manajemen Laba dan Persistensi Laba, Simposium Nasional Akuntansi XII, Palembang. 